GRASAS Y ACEITES 71 (1)

January-March 2020, e345

ISSN-L: 0017-3495

https://doi.org/10.3989/gya.1175182

\title{
Hepatoprotective effect of the unsaponifiable matter from olive, linseed and sesame oils against carbon tetrachloride-induced liver injury in rats
}

\author{
S.M. Galal ${ }^{\mathrm{a},}$, M.K.S. Morsi ${ }^{\mathrm{a}}$, M.K. Abd El-Rahman ${ }^{\mathrm{b}}$, S.K. Darwish ${ }^{\mathrm{c}}$ and M.A. Katry ${ }^{\mathrm{b}}$ \\ ${ }^{a}$ Department of Food Science, Faculty of Agriculture, Cairo University, 12613 Giza, Egypt. \\ ${ }^{b}$ National Nutrition Institute, Ministry of Health and Population, Cairo 11562, Egypt. \\ ${ }^{c}$ National Organization for Drug Control and Research, Ministry of Health and Population, 12553 Giza, Egypt. \\ Corresponding author: asadgalal@agr.cu.edu.eg
}

Submitted: 19 November 2018; Accepted: 15 March 2019; Published online: 15 January 2020

SUMMARY: In the present study, the hepatoprotective activity of the unsaponifiable matter (UNSAP) of olive oil, linseed, and sesame oils against $\mathrm{CCl}_{4}$-induced liver toxicity in rats was investigated. In a preliminary antioxidant study, UNSAP showed pronounced DPPH radical scavenging activity ( $\mathrm{IC}_{50} 6.2-10.8 \mathrm{mg} / \mathrm{mL}$ ). The constituents of UNSAP were determined by GC-MS. The subcutaneous administration of $\mathrm{CCl}_{4}$, caused liver injury. The hepatoprotective effect of UNSAP was comparable to that of $\alpha$-tocopherol, a standard antioxidant agent. The co-administration of the investigated UNSAP normalized the activities of serum marker enzymes, alanine aminotransferase (ALT), and aspartate aminotransferase (AST). Furthermore, the serum alkaline phosphatase (ALP) activity and hepatic malondialdehyde (MDA) level were found to be alleviated by pre-treatment with the UNSAP. A histopathological evaluation showed marked improvement in the liver of UNSAP- and $\alpha$-Tocopheroltreated animals. The hepatoprotective effect could be attributed to the antioxidant characteristics of UNSAP.

KEYWORDS: CCl4; Hepatotoxicity; Histopathology; Rat; Unsaponifiable matter

RESUMEN: Efecto hepatoprotector del insaponificable de los aceites de oliva, linaza y sésamo contra la lesión hepática inducida por tetracloruro de carbono en ratas. En el presente estudio, se investigó la actividad hepatoprotectora de la materia insaponificable (UNSAP) de los aceites de oliva, linaza y sésamo contra la toxicidad hepática inducida por $\mathrm{CCl} 4$ en ratas. En un estudio preliminar de antioxidantes, UNSAP mostró una pronunciada actividad de captación de radicales DPPH (IC50 6.2-10.8 mg / mL). Los constituyentes del UNSAP fueron determinados por GC-MS. La administración de CCl4, por vía subcutánea, causó lesión hepática. El efecto hepatoprotector del UNSAP fue comparable al del $\alpha$-Tocoferol, un agente antioxidante estándar. La administración conjunta del UNSAP normalizó las actividades de las enzimas marcadoras séricas, alanina aminotransferasa (ALT) y aspartato aminotransferasa (AST). Además, se encontró que la actividad de la fosfatasa alcalina en suero (ALP) y el nivel de malondialdehído hepático (MDA) se mitigan con el tratamiento previo con UNSAP. La evaluación histopatológica mostró una mejoría notable en el hígado de los animales tratados con UNSAP y $\alpha$-Tocopherol. El efecto hepatoprotector podría atribuirse a las características antioxidantes de UNSAP.

PALABRAS CLAVE: CCl4; Hepatotoxicidad; Histopatología; Materia insaponificable; Rata

ORCID ID: Galal SM https://orcid.org/0000-0002-1859-1641, Morsi MKS https://orcid.org/0000-0003-2061-6075, Abd El-Rahman MK https://orcid.org/0000-0003-0474-3023, Darwish SK https://orcid.org/0000-0001-7480-160X, Katry MA https://orcid.org/0000-0002-2857-671X

Citation/Cómo citar este artículo: Galal SM, Morsi MKS, Abd El-Rahman MK, Darwish SK, Katry MA. 2020. Hepatoprotective effect of the unsaponifiable matter from olive, linseed and sesame oils against carbon tetrachlorideinduced liver injury in rats. Grasas Aceites 71 (1), e345. https://doi.org/10.3989/gya.1175182

Copyright: (C2020 CSIC. This is an open-access article distributed under the terms of the Creative Commons Attribution 4.0 International (CC BY 4.0) License. 


\section{INTRODUCTION}

The liver has a wide range of vital functions for the human body. It detoxifies toxic substances that cause oxidative damages. Liver injury induced by carbon tetrachloride $\left(\mathrm{CCl}_{4}\right)$ is a commonly used model for screening the hepatoprotective activity of natural compounds. The toxicity of $\mathrm{CCl}_{4}$ is a result of its biotransformation to the highly reactive tri-chloromethyl, and tri-chloro-methyl peroxy free radicals. Both radicals cause the oxidative degradation of lipids, loss in integrity of cell membranes, and damage to hepatic tissue (Zhou et al., 2010). Free radicals in living cells caused structural damage, cytotoxic effects, and health problems, but they are eliminated by antioxidant systems. Plant bioactive compounds include hydrophilic antioxidants (such as polyphenols and vitamin C) and lipophilic antioxidants (such as carotenoids and tocopherols) that are used to overcome those harmful effects (Nicco and Batteux, 2018).

Crude linseed oil, extra virgin olive oil, and crude sesame oil are traditionally edible oils. Feeding piglets a 5\% flaxseed oil diet for 3 weeks alleviated liver damage induced by lipopolysaccharide and reduced serum ALT, AST and ALP activities (Wang et al., 2018). These effects were ascribed to the high level of $\alpha$-linolenic acid in this oil (Hendawi et al., 2016). Treating male rats with olive oil at $1 \mathrm{~mL} / \mathrm{kg}$ body weight (b.w) orally for 4 weeks diminished the toxic effects of $\mathrm{CCl}_{4}$ (Al-Seeni et al., 2016). The beneficial effect of extra virgin olive oil was attributed to squalene. It quenches free radicals and prevents lipid peroxidation (Reddy and Couvreur, 2009). Olive oil can be separated into a larger fraction (saponifiable) and a minor fraction that is composed of two types of components, the UNSAP fraction and the soluble part (phenolic compounds). Hydroxytyrosol is one of the major phenolic compounds of olive oil that exhibits a radical scavenging activity and protective effect against liver damage caused by a high fat diet (Echeverría et al., 2017).

Sesame oil unsaponifiables (sesamin, sesamolin, sesamol, and $\gamma$-tocopherol) have antioxidant activity (Fukuda et al., 1986). The supplementation of sesame oil at $0.5 \mathrm{~mL} / \mathrm{kg}$ b.w/day, p.o. for 14 days attenuated hepatic injury in mice induced by the long-term treatment of Ketoconazole (Periasamy et al., 2016).

The UNSAP fraction represents a "fingerprint" of each oil. It is present in considerable amounts in crude oils. It contains hydrocarbons, sterols, triterpene alcohols, and tocopherols (Fontanel, 2013). These nonglyceride components have antioxidant activity and play an important role in protecting against many diseases (Narasinga, 2001). Feeding male rats $(100 \pm 5 \mathrm{~g})$ one $\mathrm{g}$ of UNSAP from ghee, orally, for 8 days caused a marked decrease in the proliferation of lymphocytes (derived from spleen or blood), and did not affect the percent aggregation or rate of aggregation of platelets (Niranjan et al., 1999). The No Observed Adverse Effect
Level (NOAEL) of $\alpha$-tocopherol in a 13 -week oral (gavage) toxicity study in rats was $125 \mathrm{mg} / \mathrm{kg} \mathrm{b.w} /$ day (European Food Safety Authority, 2015). A pretreatment of human hepatoma (HepG2) cells with UNSAP from rice bran oil prevented the oxidative damage of tert-butyl hydroperoxide, as determined by cell cytotoxicity (Ham et al., 2016).

There are limited data in the literature on the hepatoprotective effect of UNSAP. The current study was designed to evaluate the antioxidant activity and hepatoprotective effect of UNSAP from linseed oil, extra virgin olive oil, and crude sesame seed oil in $\mathrm{CCl}_{4}$.intoxicated rats.

\section{MATERIALS AND METHODS}

\subsection{Materials}

\subsubsection{Crude oils, kits and chemicals}

Linseed oil, extra virgin olive oil, and sesame oil were obtained from Tanta Oil and Soap Company (Egypt), Agriculture Research Center, Giza, Egypt, and private Mill, Cairo, Egypt, respectively.

Kits used for the determination of ALT, AST, and ALP were obtained from the Spinreact Company (Girona, Spain). Kits used for the determination of superoxide dismutase (SOD), glutathione (GSH), catalase (CAT), and MDA were obtained from the Biodiagnostic Company for Diagnostic and Research Reagents (Cairo, Egypt). $\alpha$-tocopherol was purchased from Hoffman La Roche (Basel, Switzerland). All other chemicals and reagents were of analytical grade.

\subsubsection{Experimental animals}

Forty-two Sprague-Dawley male rats weighing $170 \pm 10 \mathrm{~g}$ were obtained from The Holding Company for Biological Products and Vaccines, Egypt. The study was carried out in accordance with ethical procedures approved by the Institutional Animal Care and Use Committee of Cairo University, Giza, Egypt (Approval number CU II F 31 17). All institutional and national guidelines for the care and use of laboratory animals were followed.

\subsection{Methods}

\subsubsection{Quality characteristics of oils}

Acid value, peroxide value, and UNSAP of the investigated crude oils were determined according to AOCS (2009).

\subsubsection{Extraction of UNSAP}

Extraction of UNSAP from the oils was carried out according to AOCS (2009) under conditions which prevent oxidation during the saponification 
process by using pyrogallol as antioxidant as follows: The oil sample $(100 \mathrm{~g})$ was saponified with pyrogallol ethanolic potassium hydroxide solution (1 N) by heating under reflux for $2 \mathrm{~h}$. After cooling, distilled water was added and mixed well. The unsaponifiable matter was extracted twice with diethyl ether using a separating funnel. The upper layers were collected, combined and washed with distilled water until they became alkali free before drying over sodium sulphate, anhydrous. The solution was evaporated under vacuum using a rotary evaporator at $40{ }^{\circ} \mathrm{C}$. The extraction of UNSAP from each oil was repeated to prepare the required quantity of UNSAP for analysis and the biological experiment.

\subsubsection{Gas chromatographic analysis of the UNSAP}

The UNSAP were analyzed using the gas chromatograph Thermo Scientific, Trace GC ultra/ISQ, USA, equipped with single quadruple MS, and TG-5MSfused silica capillary column $(30 \mathrm{~m}, 0.25 \mathrm{~mm}, 0.1 \mathrm{~mm}$ film thickness). The column temperature was programmed from 260 to $300{ }^{\circ} \mathrm{C}$ while the injection temperature was set at $280^{\circ} \mathrm{C}$. The helium flow rate was set at $1 \mathrm{~mL} / \mathrm{min}$. The identification of peaks was based on the retention time of standard substances and MS spectra of the NIST Mass Spectral Database. The calculation of percent composition of the identified components was based on peak area.

\subsubsection{DPPH radical scavenging activity}

The DPPH radical scavenging activity of the investigated UNSAP was determined according to Ramadan et al., (2008). Two hundred microliters of butanol solution of the UNSAP or the standard antioxidant ( $\alpha$-tocopherol) at different concentrations were added to $0.8 \mathrm{~mL}$ of a DPPH methanolic solution. The mixture was shaken and left at room temperature for $30 \mathrm{~min}$ in the dark. The absorbance of the resulting solution was then measured at 517 $\mathrm{nm}$. The antiradical activity was expressed as $\mathrm{IC}_{50}$ $(\mathrm{mg} / \mathrm{mL})$, the dose required to inhibit $50 \%$ of the radicals. A lower $\mathrm{IC}_{50}$ value corresponds to a higher antioxidant activity. The ability to inhibit the DPPH radicals was calculated using the following equation:

$$
\text { Inhibition } \%=(A o-A s) /(A o) \times 100
$$

where $\mathrm{A}_{0}$ is the absorbance of the blank, and $\mathrm{A}_{\mathrm{s}}$ is the absorbance of the sample. All samples were analyzed in three replicates.

\subsubsection{Experimental design}

The rats were housed in individual cages in the animal house of the National Nutrition Institute, Ministry of Health and Population, Egypt. A basal diet was prepared according to AOAC (2005) and water was given ad-libitum. The animals were kept under normal laboratory conditions for 1 week for adaptation. The rats were randomly divided into seven equal groups, each of six rats. The experimental design of Jain et al., (2008) was followed with some modifications as follows:

G1: Negative control group received olive oil (1 $\mathrm{mL} / \mathrm{kg}$ b.w, subcutaneous (s.c.)) on days $2,3,7,8$.

G2: Positive $\mathrm{CCl}_{4}$ control group received a $1: 1$ mixture of $\mathrm{CCl}_{4}$, and olive oil ( $2 \mathrm{~mL} / \mathrm{kg} \mathrm{b.w}$, s.c.) on days $2,3,7$, and 8 .

G3 and G4: $\alpha$-tocopherol groups were treated with the standard $\alpha$-tocopherol, (10 and $50 \mathrm{mg} / \mathrm{kg}$ b.w, respectively, oral administration (p.o.)) daily for 10 days and also received the same $\mathrm{CCl}_{4}$-olive oil mixture (1:1, $2 \mathrm{ml} / \mathrm{kg} \mathrm{b.w}$, s.c.) on days 2, 3, 7 and 8, after $30 \mathrm{~min}$ of administration of $\alpha$-tocopherol.

The remaining groups (G5, G6 and G7) were administered the investigated UNSAP orally, every day for 10 days at a dose equivalent to the antioxidant activity (DPPH radical scavenging activity, $\mathrm{IC}_{50}$ ) of $10 \mathrm{mg} \alpha$-tocopherol.

G5: received $500 \mathrm{mg}$ UNSAP from linseed oil/ $\mathrm{Kg}$ b.w

G6: received $600 \mathrm{mg}$ UNSAP from olive oil/ $\mathrm{kg}$ b.w

G7 received $900 \mathrm{mg}$ UNSAP from sesame oil/ $\mathrm{kg}$ b.w

The rats in these groups (G5, G6 and G7) received the same $\mathrm{CCl}_{4}$-olive oil mixture $(1: 1,2$ $\mathrm{mL} / \mathrm{kg}$ b.w, s.c.) on days $2,3,7$, and 8 , after $30 \mathrm{~min}$ of administration of the UNSAP.

On day 11 , the rats were weighed, blood samples were collected, and diethyl ether anaesthetized animals were scarified by cervical dislocation.

\subsubsection{Blood samples}

Animals were fasted for $8 \mathrm{~h}$ before blood sampling. Blood was collected from the portal hepatic vein in serum and heparin glass tubes. The serum samples were obtained after centrifugation of the coagulated blood at $950 \mathrm{x} \mathrm{g}$, for $15 \mathrm{~min}$ at $4{ }^{\circ} \mathrm{C}$. Serum samples were then stored at $-20^{\circ} \mathrm{C}$, until analysis. The heparinized whole blood was centrifuged at $950 \mathrm{x}$ g for $15 \mathrm{~min}$ at $4{ }^{\circ} \mathrm{C}$; the plasma layer was collected and stored at $-20{ }^{\circ} \mathrm{C}$ until analysis. The erythrocyte pellets were washed three times with cold physiological saline $(0.9 \% \mathrm{w} / \mathrm{v})$, and stored at $-80^{\circ} \mathrm{C}$ until analysis.

\subsubsection{Preparation of tissue supernatant}

Immediately after scarifying the rats, the liver organ of each rat was dissected out, washed with cold physiological saline $(0.9 \% \mathrm{w} / \mathrm{v})$, blotted dry, and weighed. Liver tissue samples were homogenized with a cold buffer $(50 \mathrm{mM}$ potassium phosphate, $\mathrm{pH} 7.5$ ), and centrifuged at $950 \mathrm{x}$ for $15 \mathrm{~min}$. The supernatant was collected, and stored at $-80^{\circ} \mathrm{C}$ for biochemical analysis. 


\subsubsection{Measurement of serum ALT, AST and ALP}

The determination of blood serum AST, ALT, and ALP activities were carried out using commercial kits according to the manufacturers' protocols.

\subsubsection{Measurement of antioxidant enzyme activities and $M D A$}

Whole blood was used for the determination of GSH. Blood plasma was used for the determination of MDA level and CAT activity while blood erythrocyte lysate was used for the determination of SOD activity. The clear supernatant of liver homogenate was used for the measurement of GSH, SOD, CAT activities, and MDA level. Biochemical determinations were carried out using kits according to the manufacturers' protocols.

\subsubsection{Histopathological evaluation of liver tissue}

The liver specimens were taken from the rats and fixed with $10 \%$ neutral formalin for $72 \mathrm{~h}$ before proceeding with the preparation of $5 \mu \mathrm{m}$-thick paraffin sections. These sections were sequentially stained with Hematoxylin and Eosin ( $\mathrm{H} \& \mathrm{E}$ ) for histopathological examination using light microscope according to Bancroft et al., (1996).

\subsubsection{Statistical analyses}

Results were reported as mean \pm S.D. The data were analyzed by one-way ANOVA and Tukey's test. A bivariate analysis of the data was carried out by Pearson's correlation test. A value of $p<0.05$ was considered statistically significant. Statistical analyses were performed with Minitab Statistics software version 17 (Minitab Inc., USA).

\section{RESULTS AND DISCUSSION}

\subsection{Quality characteristics of oils and chemical composition of the extracted UNSAP}

The freshness of the investigated oils was confirmed and their acid and peroxide values were compatible with the Codex Alimentarius (2015). Linseed oil had the lowest content of UNSAP fraction $(0.8 \%)$. Olive oil and sesame seed oils were characterized by a higher content of UNSAP fraction, which amounted to 1.7 and $2.5 \%$, respectively (Table 1). These results are in agreement with those reported by Fontanel (2013).

Gas chromatographic analysis data of the extracted UNSAP are shown in Table 1. GC-MS data indicated that UNSAP from linseed oil contained $\gamma$-tocopherol $(5.43 \%)$, sterols $(13.91 \%)$, and hydrocarbons. $\alpha$-tocopherol was not detected in the UNSAP of linseed oil as reported by
Gliszczynska-Swiglo et al., (2007). Squalene represented the main component $(96.14 \%)$ of olive oil UNSAP. Negligible levels $(0.8 \%)$ of sterols, and $\alpha$-tocopherol were found in this UNSAP. Olive oil represents the highest source of squalene, compared to other oils (Reddy and Couvreur, 2009). The UNSAP from sesame oil contained sterols $(43.86 \%)$, sesamin $(28.95 \%)$, and $\gamma$-tocopherol (18.44\%). Gamma-tocopherol is the major tocopherol in sesame oil (Codex Alimentarius, 2015), while sesamin is considered the predominant constituent of lignans in crude sesame oil (Moazzami et al., 2007). In addition, phytol is present in considerable quantities in UNSAP from linseed oil and sesame oil as reported by Krauß and Vetter (2018).

\subsection{In vitro radical scavenging activity by DPPH assay}

The scavenging activity of the investigated UNSAP against DPPH radicals is shown in Table 2. $\alpha$-tocopherol was used as a positive control.

In the present study, the antioxidant activity of the UNSAP from linseed oil $\left(\mathrm{IC}_{50}=6.2 \mathrm{mg} / \mathrm{mL}\right)$ was close to that of the UNSAP from olive oil $(7.3 \mathrm{mg} /$ $\mathrm{mL})$. The radical scavenging activity of the UNSAP from sesame oil $\left(\mathrm{IC}_{50}=10.8 \mathrm{mg} / \mathrm{mL}\right)$ represented less than $50 \%$ of the activity of the other investigated UNSAP. Farhoosh et al., (2013) reported that the UNSAP fraction of the sesame oil had no scavenging activity against the DPPH free radicals at the concentrations studied. The $\mathrm{IC}_{50}$ value of $\alpha$-tocopherol was found to be $121.32 \mu \mathrm{g} / \mathrm{mL}$, which is in agreement with that reported by Yildiztekin et al., (2016). This means that the antioxidant activity of $\alpha$-tocopherol was 50, 60, and 90 times that of the UNSAP of linseed oil, olive oil and sesame seed oil, respectively. This ratio helps in selecting the hepatoprotective dose levels of the investigated UNSAP. The hepatoptotective activity of a dose of $10 \mathrm{mg} \alpha$-tocopherol/Kg b.w/day was evaluated in comparison with the doses of $500 \mathrm{mg}$ UNSAP of linseed oil/Kg b.w/day, $600 \mathrm{mg}$ UNSAP of olive oil/ $\mathrm{Kg}$ b.w/day, and $900 \mathrm{mg}$ UNSAP of sesame oil/Kg b.w/day. One should keep in mind that each investigated UNSAP is a mixture of several compounds and hence may affect, in part, its efficiency as antioxidant compared to pure $\alpha$-tocopherol.

\subsection{Effect of $\alpha$-tocopherol and UNSAP on liver functions of CCl4-intoxicated rats}

The activities of the AST, ALT, and ALP enzymes in the serum of the rats are presented in Table 3.

The administration of $\mathrm{CCl}_{4}$ induced hepatic injury as evidenced by a significant $(p<0.05)$ elevation of serum AST, ALT, and ALP activities ( three-fold) compared to the normal control group is shown in Table 3. The pre-treatment of $\mathrm{CCl}_{4}$ intoxicated rats 
TABLE 1. Quality characteristics of oils and GC-MS identified components of unsaponifiable matter

\begin{tabular}{|c|c|c|c|c|c|}
\hline \multicolumn{3}{|c|}{ Parameter } & Linseed oil & Olive oil & Sesame oil \\
\hline \multicolumn{3}{|c|}{ Acid value (mg KOH/g Oil) } & $0.26 \pm 0.01$ & $0.57 \pm 0.01$ & $0.90 \pm 0.02^{\mathrm{a}}$ \\
\hline \multicolumn{3}{|c|}{ Peroxide value ( $\mathrm{mEq} \mathrm{O}_{2} / \mathrm{kg}$ oil) } & $3.25 \pm 0.04$ & $6.50 \pm 0.05$ & $2.80 \pm 0.15$ \\
\hline \multicolumn{3}{|c|}{ Unsaponifiable matter $\%$} & $0.80 \pm 0.03$ & $1.70 \pm 0.05$ & $2.50 \pm 0.01$ \\
\hline \multicolumn{6}{|c|}{ Unsaponifiable components (Relative Area \%) } \\
\hline $\mathbf{R T}^{\mathrm{b}}$ & Name & $\mathbf{M W}^{\mathrm{c}}$ & & & \\
\hline 30.90 & Phytol & 296 & 2.66 & $\mathrm{ND}^{\mathrm{d}}$ & 4.02 \\
\hline 41.67 & Tricosane & 324 & ND & ND & 0.66 \\
\hline 43.73 & Tetracosane & 338 & ND & ND & 0.77 \\
\hline 50.12 & Tetratriacontane & 478 & 36.63 & ND & ND \\
\hline 51.38 & Squalene & 410 & ND & 96.14 & 0.88 \\
\hline 51.86 & Cycloeucalenol & 426 & ND & 0.58 & ND \\
\hline 52.12 & Pentatriacontane & 492 & 1.43 & ND & ND \\
\hline 53.10 & Triacontane & 422 & 2.10 & ND & ND \\
\hline 54.61 & Tritriacontane & 464 & 24.92 & ND & ND \\
\hline 55.56 & $\gamma$-Tocopherol & 416 & ND & 5.43 & 18.44 \\
\hline 56.80 & $\alpha$-Tocopherol & 430 & ND & 0.80 & ND \\
\hline 57.56 & Rutin & 610 & ND & ND & 1.05 \\
\hline 57.63 & Tetracontane & 562 & 10.30 & ND & ND \\
\hline 57.76 & Sesamin & 354 & ND & ND & 28.95 \\
\hline 58.46 & Campesterol & 400 & 5.84 & ND & 12.99 \\
\hline 58.83 & Stigmasterol & 412 & 1.87 & ND & 3.85 \\
\hline 59.82 & $\beta$-Sitosterol & 414 & 6.20 & 0.79 & 27.02 \\
\hline 60.00 & Cycloartenol & 426 & ND & ND & 1.38 \\
\hline 60.03 & Dotriacontane & 450 & 2.62 & ND & ND \\
\hline 62.04 & 24-methylenecycloartanol & 440 & ND & 0.77 & ND \\
\hline 63.36 & $\begin{array}{l}\text { 6-[3-[3-[3-(5,11 dioxoindeno [1,2-c]isoquinolin-6-yl) } \\
\text { propylamino] propylamino] propyl] indeno }[1,2-\mathrm{c}] \\
\text { isoquinoline-5,11-dione }\end{array}$ & 648 & ND & 0.91 & ND \\
\hline
\end{tabular}

${ }^{a}$ Mean \pm Standard Deviation $(\mathrm{n}=3)$.

${ }^{\mathrm{b}} \mathrm{RT}$ : Retention time in minutes.

${ }^{c}$ MW: Molecular weight.

${ }^{\mathrm{d} N D:}$ Not detected.

with the investigated UNSAP kept their AST and ALT activities not significantly $(p<0.05)$ different from those of the control group. The pre-treatment with the UNSAP from linseed oil and olive oil significantly $(p<$ 0.05 ) reduced the activity of ALP compared with the $\mathrm{CCl}_{4}$ group. Likewise, the UNSAP from sesame seed oil suppressed significantly $(p<0.05)$ the ALP activity of $\mathrm{CCl}_{4}$ intoxicated rats to the normal level. These results indicate that the investigated UNSAP have noticeable antioxidant efficacy against $\mathrm{CCl}_{4}$ radicals.

The UNSAP doses were sufficient to overcome the destructive effect of $\mathrm{CCl}_{4}$ on liver enzymes. The antioxidant activity of each UNSAP could be attributed to the synergistic effect of its constituents.

The administration of $\alpha$-tocopherol (a positive control) at both investigated doses in $\mathrm{CCl}_{4}$-treated rats significantly $(p<0.05)$ lowered the activity of AST compared with the $\mathrm{CCl}_{4}$-treated group and
TABLE 2. DPPH radical scavenging activity of the investigated unsaponifiable matter

\begin{tabular}{lc}
\hline Unsaponifiable matter & $\mathbf{I C}_{\mathbf{5 0}}{ }^{\mathbf{a}}(\mathbf{m g} / \mathbf{m L})$ \\
\hline Linseed oil & $6.20 \pm 0.08^{\mathrm{b}}$ \\
Olive oil & $7.30 \pm 0.16$ \\
Sesame oil & $10.80 \pm 0.35$ \\
\hline
\end{tabular}

${ }^{\mathrm{a}} \mathrm{IC}_{50}$ value denote the concentration of sample, which is required to scavenge $50 \%$ of DPPH free radicals. $\mathrm{IC}_{50}$ value of $\alpha$-tocopherol was found to be $121.32 \pm 0.48(\mu \mathrm{g} / \mathrm{mL})$.

${ }^{\mathrm{b}}$ Mean \pm Standard Deviation $(\mathrm{n}=3)$.

reduced ALT activity to the normal level. However, the rats pre-treated with $\alpha$-tocopherol at $50 \mathrm{mg} / \mathrm{Kg}$ b.w significantly decreased the activity of ALP, compared to the $\mathrm{CCl}_{4}$ group. Although the nutritional value of $\alpha$-tocopherol is higher than the other forms of tocopherols, $\gamma$-tocopherol is biologically active 
TABLE 3. Liver function and oxidative stress biomarkers in the blood of $\mathrm{CCL}_{4}$ - intoxicated rats treated with unsaponifiable matter and $\alpha$-tocopherol

\begin{tabular}{|c|c|c|c|c|c|c|c|}
\hline $\begin{array}{l}\text { Parameter } \\
\text { Group }\end{array}$ & $\begin{array}{c}\text { AST } \\
(\mathrm{U} / \mathrm{L})\end{array}$ & $\begin{array}{c}\text { ALT } \\
(\mathbf{U} / \mathbf{L})\end{array}$ & $\begin{array}{l}\text { ALP } \\
(\mathbf{U} / \mathbf{L})\end{array}$ & $\begin{array}{c}\text { GSH } \\
(\mathrm{mg} / \mathrm{dL})\end{array}$ & $\begin{array}{c}\text { SOD } \\
(\mathrm{U} / \mathrm{mL})\end{array}$ & $\begin{array}{c}\text { CAT } \\
(\mathrm{U} / \mathrm{L})\end{array}$ & $\begin{array}{c}\text { MDA } \\
(\mathrm{nmol} / \mathrm{mL})\end{array}$ \\
\hline Control & $\begin{array}{r}82.33 \\
\pm 3.06^{\mathrm{c}}\end{array}$ & $\begin{array}{l}65.00 \\
\pm 4.36^{\mathrm{b}}\end{array}$ & $\begin{array}{l}119.00 \\
\pm 11.79^{\mathrm{d}}\end{array}$ & $\begin{array}{r}26.85 \\
\pm 0.98^{\mathrm{a}}\end{array}$ & $\begin{array}{l}365.38 \\
\pm 4.81^{\mathrm{a}}\end{array}$ & $\begin{array}{l}435.30 \\
\pm 29.50^{\mathrm{b}}\end{array}$ & $\begin{aligned} & 9.23 \\
\pm & 1.44^{\mathrm{bc}}\end{aligned}$ \\
\hline $\mathrm{CCl}_{4}$ & $\begin{array}{l}239.30 \\
\pm 35.20^{\mathrm{a}}\end{array}$ & $\begin{array}{l}160.67 \\
\pm 17.01^{\mathrm{a}}\end{array}$ & $\begin{array}{r}283.67 \\
\pm 3.21^{\mathrm{a}}\end{array}$ & $\begin{array}{l}17.52 \\
\pm 1.70^{c}\end{array}$ & $\begin{array}{l}328.80 \\
\pm 27.10^{b}\end{array}$ & $\begin{array}{l}286.30 \\
\pm 19.50^{c}\end{array}$ & $\begin{array}{l}19.56 \\
\pm 0.75^{\mathrm{a}}\end{array}$ \\
\hline $\begin{array}{l}\alpha \text {-Tocopherol } \\
(10 \mathrm{mg} / \mathrm{Kg} \mathrm{b} . \mathrm{w})+\mathrm{CCl}_{4}\end{array}$ & $\begin{array}{l}157.67 \\
\pm 15.28^{b}\end{array}$ & $\begin{aligned} & 69.30 \\
\pm & 18.60^{\mathrm{b}}\end{aligned}$ & $\begin{array}{l}237.33 \\
\pm 25.80^{\mathrm{ab}}\end{array}$ & $\begin{array}{l}19.04 \\
\pm 0.86^{\mathrm{bc}}\end{array}$ & $\begin{array}{l}355.30 \\
\pm 4.24^{\mathrm{ab}}\end{array}$ & $\begin{array}{l}275.00 \\
\pm 47.30^{c}\end{array}$ & $\begin{array}{c}7.77 \\
\pm 2.74^{\mathrm{c}}\end{array}$ \\
\hline $\begin{array}{l}\alpha \text {-Tocopherol } \\
(50 \mathrm{mg} / \mathrm{Kg} \mathrm{b} . \mathrm{w})+\mathrm{CCl}_{4}\end{array}$ & $\begin{array}{l}158.33 \\
\pm 2.52^{\mathrm{b}}\end{array}$ & $\begin{aligned} & 55.67 \\
\pm & 10.97^{\mathrm{b}}\end{aligned}$ & $\begin{array}{l}230.70 \\
\pm 31.90^{\mathrm{bc}}\end{array}$ & $\begin{array}{l}22.88 \\
\pm 0.67^{\mathrm{ab}}\end{array}$ & $\begin{array}{l}358.11 \\
\pm 4.77^{\mathrm{ab}}\end{array}$ & $\begin{array}{l}434.70 \\
\pm 34.20^{\mathrm{b}}\end{array}$ & $\begin{aligned} & 7.93 \\
\pm & 1.42^{\mathrm{c}}\end{aligned}$ \\
\hline $\begin{array}{l}\text { Linseed oil UNSAP } \\
(500 \mathrm{mg} / \mathrm{Kg} \text { b.w })+\mathrm{CCl}_{4}\end{array}$ & $\begin{array}{l}125.67 \\
\pm 15.53^{\mathrm{bc}}\end{array}$ & $\begin{aligned} & 52.33 \\
\pm & 14.98^{\mathrm{b}}\end{aligned}$ & $\begin{array}{l}215.67 \\
\pm 4.93^{\mathrm{bc}}\end{array}$ & $\begin{array}{l}19.38 \\
\pm 1.97^{\mathrm{bc}}\end{array}$ & $\begin{array}{l}328.13 \\
\pm 5.39^{\mathrm{b}}\end{array}$ & $\begin{array}{l}513.00 \\
\pm 39.10^{\mathrm{a}}\end{array}$ & $\begin{array}{l}13.42 \\
\pm 0.94^{\mathrm{b}}\end{array}$ \\
\hline $\begin{array}{l}\text { Olive oil UNSAP } \\
(600 \mathrm{mg} / \mathrm{Kg} \mathrm{b} . \mathrm{w})+\mathrm{CCl}_{4}\end{array}$ & $\begin{array}{l}121.00 \\
\pm 4.36^{\mathrm{bc}}\end{array}$ & $\begin{array}{l}61.00 \\
\pm 7.21^{\mathrm{b}}\end{array}$ & $\begin{array}{l}187.67 \\
\pm 10.02^{\mathrm{c}}\end{array}$ & $\begin{array}{l}24.27 \\
\pm 2.17^{\mathrm{ab}}\end{array}$ & $\begin{array}{l}350.33 \\
\pm 2.47^{\mathrm{ab}}\end{array}$ & $\begin{array}{l}308.36 \\
\pm 15.57^{c}\end{array}$ & $\begin{array}{l}13.90 \\
\pm 3.25^{\mathrm{b}}\end{array}$ \\
\hline $\begin{array}{l}\text { Sesame oil UNSAP } \\
(900 \mathrm{mg} / \mathrm{Kg} \text { b.w })+\mathrm{CCl}_{4}\end{array}$ & $\begin{array}{l}127.3 \\
\pm 19.30^{\mathrm{bc}}\end{array}$ & $\begin{array}{l}69.67 \\
\pm 6.66^{\mathrm{b}} \\
\end{array}$ & $\begin{array}{l}123.00 \\
\pm 9.64^{\mathrm{d}}\end{array}$ & $\begin{array}{l}23.46 \\
\pm 3.38^{\mathrm{ab}} \\
\end{array}$ & $\begin{array}{r}364.31 \\
\pm 7.54^{\mathrm{a}} \\
\end{array}$ & $\begin{array}{l}320.90 \\
\pm 23.40^{\mathrm{b}}\end{array}$ & $\begin{array}{l}13.08 \\
\pm 1.62^{\mathrm{bc}}\end{array}$ \\
\hline
\end{tabular}

Data are expressed as Mean \pm Standard Deviation $(n=6)$. Significant differences among the means were determined by analysis of variance and Tukey's test. Means with the same letter in the same column are not significantly different at 0.05 level of significance.

and protects against chronic diseases (GliszczynskaSwiglo et al., 2007).

\subsection{Effect of $\alpha$-tocopherol and UNSAP on the oxidative status of the blood of CCl4 intoxicated rats}

The antioxidant effects of $\alpha$-tocopherol and UNSAP on the $\mathrm{CCl}_{4}$-intoxicated rats are shown in Table 3. Treating rats with $\mathrm{CCl}_{4}$ caused significant $(p<0.05)$ decreases in the GSH levels, SOD and CAT activities, and significant $(p<0.05)$ increase in serum MDA compared to those of the normal control group (Table 3). This indicates the impairment of the anti-oxidative system due to the $\mathrm{CCl}_{4}$ treatment. GSH, SOD and CAT represent the defense system against oxidative stress (Beji et al., 2018). Pre-treatment with $\alpha$-tocopherol at a low dose $(10$ $\mathrm{mg} / \mathrm{Kg} \mathrm{b.w}$ ) as well as the UNSAP of linseed oil did not prevent the GSH depletion induced by $\mathrm{CCl}_{4}$. However, pre-treatment with $\alpha$-tocopherol at a high dose or the UNSAP of olive oil or the UNSAP of sesame oil significantly $(p<0.05)$ normalized GSH levels, indicating a curative effect. Blood GSH levels fluctuated during different stages of liver injury since this level of GSH is a balance between secretion from the liver and elimination through the kidneys (Lai et al., 2018). Pre-treatment with sesame oil UNSAP prevented $\mathrm{CCl} 4$ toxicity and increased SOD activity to the normal value. Moreover, the efficiency of the investigated UNSAP on GSH level and SOD activity was comparable to that of the reference $\alpha$-tocopherol at a high dose. Pre-treatment with $\alpha$-tocopherol at a low dose or UNSAP of olive oil did not significantly $(p<0.05)$ restore CAT activity to the normal value. The administration of $\alpha$-tocopherol at $50 \mathrm{mg} / \mathrm{Kg}$ b.w or UNSAP of linseed oil or UNSAP of sesame oil significantly $(p<0.05)$ increased CAT activity to the normal level.

MDA is one of the main lipid peroxidation products. Pre-treatments of $\mathrm{CCl}_{4}$ intoxicated rats with the investigated UNSAP or $\alpha$-tocopherol at both investigated doses significantly reduced $(p<0.05)$ MDA to the normal level.

\subsection{Effect of UNSAP on oxidative status of liver tissue of CCl4-intoxicated rats}

The effects of the investigated treatments on the activities of SOD and CAT in the liver and the levels of GSH and MDA are shown in Table 4.

The activities of liver SOD, and CAT in the $\mathrm{CCl}_{4}$ treated group were significantly $(p<0.05)$ decreased compared to the normal group. The results revealed a significant $(p<0.05)$ increase in the MDA level (five times) in the $\mathrm{CCl}_{4}$-treated group compared to the control. The free radical of trichloro-methyl increases the MDA level that damages the antioxidant defense of tissues (Johnston and Kroening, 1998). GSH is essential for keeping the reduced status of tissues. Tissue injury causes severe depletion in its levels. In this study, a significant decrease in the GSH level in the liver tissue by approximately 40\% was recorded after the administration of $\mathrm{CCl}_{4}$ in comparison with the rats of the control group (Table 4).

The pre-treatment with $\alpha$-tocopherol at $50 \mathrm{mg} /$ $\mathrm{Kg}$ b.w significantly increased $(p<0.05)$ the GSH level compared to that of the $\mathrm{CCl}_{4}$-treated group. At the same time, treating $\mathrm{CCl}_{4}$-intoxicated rats with the UNSAP of linseed oil, or the UNSAP of sesame oil significantly $(p<0.05)$ increased the GSH level of liver homogenate to the normal level.

On the other hand, the administration of $\alpha$-tocopherol at $50 \mathrm{mg} / \mathrm{Kg}$ b.w or UNSAP of olive 
TABLE 4. Oxidative stress biomarkers in the liver tissue of $\mathrm{CCL}_{4}$ intoxicated rats treated with unsaponifiable matter and $\alpha$-tocopherol

\begin{tabular}{|c|c|c|c|c|}
\hline Group & $\begin{array}{c}\text { GSH } \\
\text { (mg/g tissue) }\end{array}$ & $\begin{array}{c}\text { SOD } \\
\text { (U/mg tissue) }\end{array}$ & $\begin{array}{c}\text { CAT } \\
\text { (U/g tissue) }\end{array}$ & $\begin{array}{c}\text { MDA } \\
\text { (nmol/g tissue) }\end{array}$ \\
\hline Control & $\begin{array}{l}115.54 \\
\pm 2.28^{\mathrm{a}}\end{array}$ & $\begin{array}{l}24.42 \\
\pm 0.90^{\mathrm{a}}\end{array}$ & $\begin{array}{l}155.55 \\
\pm 6.73^{\mathrm{ab}}\end{array}$ & $\begin{array}{l}23.82 \\
\pm 0.85^{\mathrm{d}}\end{array}$ \\
\hline $\mathrm{CCl}_{4}$ & $\begin{array}{l}71.97 \\
\pm 7.83^{\mathrm{c}}\end{array}$ & $\begin{array}{r}8.32 \\
\pm 1.01^{\mathrm{d}}\end{array}$ & $\begin{array}{l}129.37 \\
\pm 2.45^{\mathrm{c}}\end{array}$ & $\begin{array}{l}115.21 \\
\pm 10.56^{\mathrm{a}}\end{array}$ \\
\hline $\begin{array}{l}\alpha \text {-Tocopherol } \\
(10 \mathrm{mg} / \mathrm{Kg} \text { b.w })+\mathrm{CCl}_{4}\end{array}$ & $\begin{array}{l}80.30 \\
\pm 1.23^{\mathrm{bc}}\end{array}$ & $\begin{aligned} & 19.14 \\
+ & 3.12^{\mathrm{bc}}\end{aligned}$ & $\begin{array}{l}143.66 \\
\pm 11.49^{\mathrm{bc}}\end{array}$ & $\begin{array}{l}44.18 \\
\pm 9.17^{\mathrm{bc}}\end{array}$ \\
\hline $\begin{array}{l}\alpha \text {-Tocopherol } \\
(50 \mathrm{mg} / \mathrm{Kg} \text { b.w })+\mathrm{CCl}_{4}\end{array}$ & $\begin{array}{l}93.13 \\
\pm 5.12^{\mathrm{b}}\end{array}$ & $\begin{array}{c}22.33 \\
\pm 1.20^{\mathrm{ab}}\end{array}$ & $\begin{array}{l}171.44 \\
\pm 5.10^{\mathrm{a}}\end{array}$ & $\begin{array}{l}27.53 \\
\pm 0.92^{\mathrm{cd}}\end{array}$ \\
\hline $\begin{array}{l}\text { Linseed oil UNSAP } \\
(500 \mathrm{mg} / \mathrm{Kg} \mathrm{b.w})+\mathrm{CCl}_{4}\end{array}$ & $\begin{array}{r}118.60 \\
\pm 9.08^{\mathrm{a}}\end{array}$ & $\begin{array}{l}18.78 \\
\pm 0.59^{\mathrm{bc}}\end{array}$ & $\begin{array}{l}132.13 \\
\pm 4.56^{\mathrm{c}}\end{array}$ & $\begin{array}{l}28.35 \\
\pm 3.43^{\mathrm{cd}}\end{array}$ \\
\hline $\begin{array}{l}\text { Olive oil UNSAP } \\
(600 \mathrm{mg} / \mathrm{Kg} \mathrm{b.w})+\mathrm{CCl}_{4}\end{array}$ & $\begin{aligned} & 76.21 \\
& \pm 10.26^{\mathrm{bc}}\end{aligned}$ & $\begin{array}{l}20.10 \\
\pm 2.78^{\mathrm{abc}}\end{array}$ & $\begin{array}{l}156.85 \\
\pm 3.43^{\mathrm{ab}}\end{array}$ & $\begin{array}{l}47.09 \\
\pm 3.95^{\mathrm{b}}\end{array}$ \\
\hline $\begin{array}{l}\text { Sesame oil UNSAP } \\
(900 \mathrm{mg} / \mathrm{Kg} \mathrm{b} . \mathrm{w})+\mathrm{CCl}_{4}\end{array}$ & $\begin{array}{r}115.17 \\
\pm 8.94^{\mathrm{a}} \\
\end{array}$ & $\begin{array}{l}15.58 \\
\pm 0.78^{\mathrm{c}}\end{array}$ & $\begin{array}{l}144.20 \\
\pm 9.32^{\mathrm{bc}}\end{array}$ & $\begin{array}{l}51.96 \\
\pm 7.62^{\mathrm{b}} \\
\end{array}$ \\
\hline
\end{tabular}

Data are expressed as Mean \pm Standard Deviation $(n=6)$. Significant differences among the means were determined by analysis of variance and Tukey's test. Means with the same letter in the same column are not significantly different at 0.05 level of significance.

TABLE 5. Pearson's correlation coefficient (r) between liver function enzymes and the oxidative stress biomarkers in the different groups studied

\begin{tabular}{|c|c|c|c|c|c|c|c|c|c|c|}
\hline Parameter & AST & ALT & ALP & $\begin{array}{l}\text { Blood } \\
\text { MDA }\end{array}$ & $\begin{array}{l}\text { Liver } \\
\text { MDA }\end{array}$ & $\begin{array}{l}\text { Blood } \\
\text { GSH }\end{array}$ & $\begin{array}{l}\text { Liver } \\
\text { GSH } \\
\end{array}$ & $\begin{array}{l}\text { Blood } \\
\text { SOD } \\
\end{array}$ & $\begin{array}{l}\text { Liver } \\
\text { SOD } \\
\end{array}$ & $\begin{array}{l}\text { Blood } \\
\text { CAT }\end{array}$ \\
\hline ALT & $0.746^{* *}$ & & & & & & & & & \\
\hline ALP & $0.794^{* *}$ & $0.529^{*}$ & & & & & & & & \\
\hline Blood MDA & $0.499^{*}$ & $0.629^{* *}$ & 0.241 & & & & & & & \\
\hline Liver MDA & $0.779^{* *}$ & $0.933^{* *}$ & $0.530^{*}$ & $0.721^{* *}$ & & & & & & \\
\hline Blood GSH & $-0.705^{* *}$ & $-0.515^{*}$ & $-0.748^{* *}$ & -0.302 & $-0.538^{*}$ & & & & & \\
\hline Liver GSH & $-0.662^{* *}$ & $-0.491^{*}$ & $-0.633^{* *}$ & -0.287 & $-0.556^{* *}$ & 0.386 & & & & \\
\hline Blood SOD & $-0.579^{* *}$ & -0.381 & $-0.602^{* *}$ & $-0.529^{*}$ & -0.382 & $0.672^{* *}$ & 0.279 & & & \\
\hline Liver SOD & $-0.774^{* *}$ & $-0.811^{* *}$ & $-0.493^{*}$ & $-0.709^{* *}$ & $-0.888^{* *}$ & $0.602^{* *}$ & 0.355 & $0.499^{*}$ & & \\
\hline Blood CAT & $-0.433^{*}$ & $-0.469^{*}$ & -0.207 & -0.205 & $-0.615^{* *}$ & 0.215 & $0.643^{* *}$ & -0.042 & $0.498^{*}$ & \\
\hline Liver CAT & -0.412 & $-0.529^{*}$ & -0.313 & $-0.585^{* *}$ & $-0.549^{* *}$ & $0.619^{* *}$ & 0.042 & $0.605^{* *}$ & $0.706^{* *}$ & 0.158 \\
\hline
\end{tabular}

* Significant at $p<0.05$.

$* *$ Significant at $p<0.01$.

oil in $\mathrm{CCl}_{4}$-treated rats significantly $(p<0.05)$ increased the activities of SOD and CAT in the liver tissue to the normal value. Hydroxytyrosol, the major phenolic compound in extra virgin olive oil, has the ability to activate GSH biosynthesis and attenuate the increase of TBARs (Illesca et al., 2019). Treatments with $\alpha$-tocopherol showed a dose-dependent increase in the GSH levels and activities of SOD and CAT compared to the control group.

In the present study, the MDA level of liver tissue was significantly reduced after the administration of $\alpha$-tocopherol or the investigated UNSAP. The administration of $\alpha$-tocopherol at a high dose as well as the UNSAP of linseed oil in $\mathrm{CCl}_{4}$-treated rats significantly $(p<0.05)$ decreased the MDA level of liver tissue to the normal value.
The data showed that all UNSAP studied contained several compounds at varied concentrations. The antioxidant effect of these UNSAP is, actuality, the accumulative effect of its constituents and could not be directly attributed to one single compound in the mixture.

The correlation between the investigated parameters using Pearson's Correlation is shown in Table 5.

The results revealed significant $(p<0.01)$ positive correlations among the activities of liver function enzymes. The results indicated an inverse $(p<$ 0.01 ) correlation between the activities of liver function enzymes and SOD and GSH levels. In addition, the CAT activity in the liver had a significant $(p<$ $0.01)$ positive correlation with the activity of SOD in the liver and blood. A significant $(p<0.01)$ positive correlation between the MDA levels in the liver 
(a)

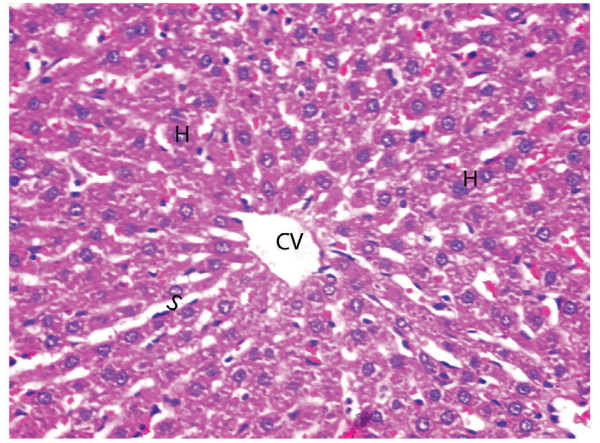

(c)

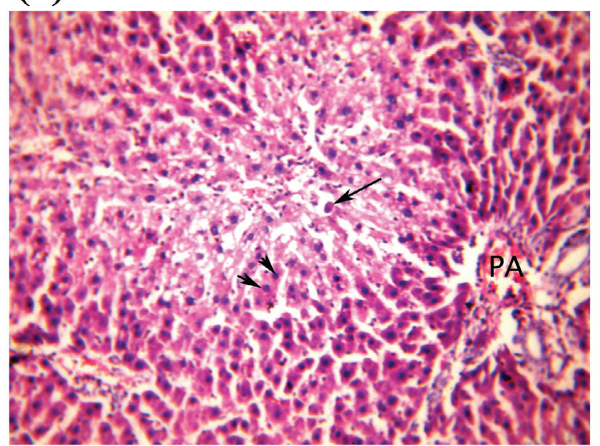

(e)

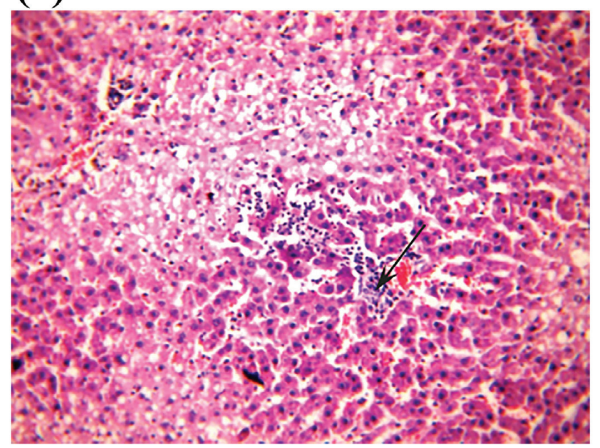

(b)

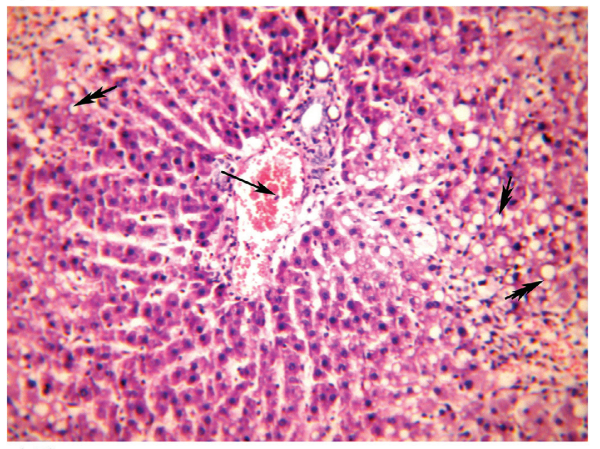

(d)

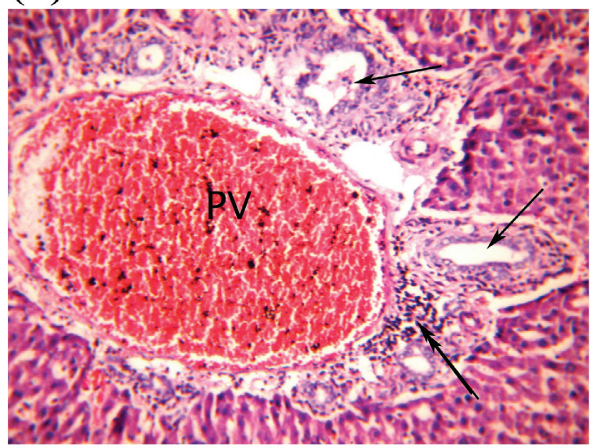

(f)

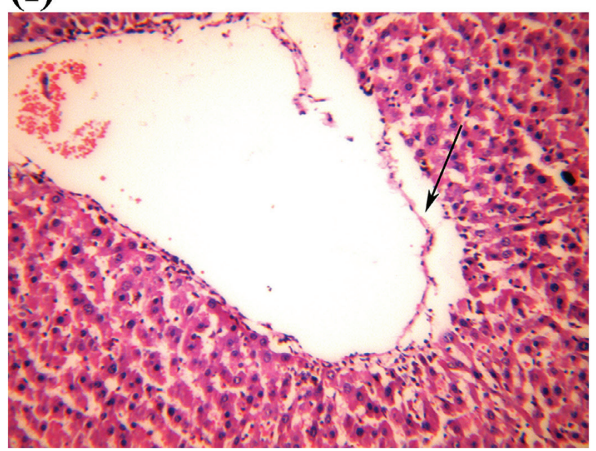

(g)

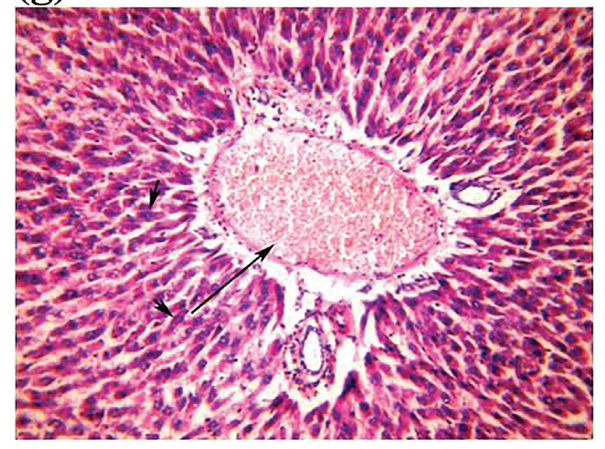

FIGURE 1. Photomicrographs of liver sections of $\mathrm{CCl}_{4}$-treated rats administered with Unsaponifiable matter and $\alpha$-tocopherol (a-g). (a) Control group showing normal hepatocytes $(\mathrm{H})$, normal sized sinusoids $(\mathrm{S})$ and central vein $(\mathrm{CV})$. (b) $\mathrm{CCl}_{4}$ intoxicated rats, showing steatotic hepatocytes (arrowhead), and congested portal vein (arrow). (c) $\mathrm{CCl}_{4}$ intoxicated rats treated with $\alpha$-tocopherol (10 mg/kg b.w) showing hyaline body (arrow), apoptotic hepatocytes (arrowhead) and restricted portal area (PA). (d) CCl $\mathrm{Cl}_{4}$ intoxicated rats treated with $\alpha$-tocopherol $(50 \mathrm{mg} / \mathrm{kg} \mathrm{b.w}$ ) showing proliferated bile duct (arrow), periportal inflammation (double arrow) and dilated congested portal vein (PV). (e) $\mathrm{CCl}_{4}$ intoxicated rats treated with the unsaponifiable matter of linseed oil, showing inflammatory cell aggregates (arrow). (f) $\mathrm{CCl}_{4}$.intoxicated rats treated with the unsaponifiable matter of olive oil, showing improvement of most hepatocytes, and lacerated wall of central vein (arrow). ( $\mathrm{g}$ ) $\mathrm{CCl}_{4}$.intoxicated rats treated with the unsaponifiable matter of sesame oil, showing dilated, congested blood vessel (arrow), where most hepatocytes display normal (arrowhead). (Haematoxylin \& Eosin×200) 
and blood was observed. On the other hand, the activity of hepatic SOD significantly $(p<0.01)$ and negatively correlated with the MDA levels in both blood and liver. However, no statistical significant correlation was found between the GSH levels in the liver and blood of the investigated rats. The same trend was observed in the CAT levels in the liver and blood.

\subsection{Histopathological examination}

A microscopical examination of the hepatic tissues of the control group revealed normal liver structure with a normal lobular pattern. The hepatocytes showed well-defined central nuclei and abundant cytoplasm. Magnification at 200x enabled the observation of the normality of the central vein and portal venous channels with normal-sized sinusoids. Bile ducts were lined with normal cuboidal epithelium. (Figure 1a).

A histopathological examination of the hepatic tissues of the $\mathrm{CCl}_{4}$ group showed a weaker architecture, with edema. Most of the hepatic vasculature revealed congestion, dilatation, and inflammation. Hepatocytes showed steatosis and severe cytoplasmic vacuolation (Figure $1 \mathrm{~b}$ ). These results are in accordance with those obtained by Beji et al., (2018).

The treatment of intoxicated rats with $\alpha$-tocopherol at $10 \mathrm{mg} / \mathrm{Kg}$ b.w revealed a mild degree of improvement, where disturbed architecture with expanded portal areas was observed. A hyaline body with a fragmented nucleus and apoptotic hepatocytes were also seen (Figure 1c). Increasing the dose level of $\alpha$-tocopherol to $50 \mathrm{mg} / \mathrm{Kg}$ b.w caused a moderate degree of improvement, where wide areas of hepatocytes displayed normal features. However, necrotic areas with hyaline body were observed (Figure 1-d). This finding was consistent with that found by Liu et al., (2011).

A histological picture of the hepatocytes of UNSAP of the linseed oil group indicated mild to moderate curative effects. The examination revealed areas of intact hepatocytes alternated with areas of hepatocytes with vacuolated cytoplasm or fatty degeneration (Figure 1e). Insignificant pathological changes were detected in animals treated with the UNSAP of olive oil, where most of the hepatocytes displayed normal histological patterns, indicating a marked improvement. However, $30 \%$ of the animals displayed congested central veins with lacerated walls together with mild inflammation (Figure 1f). A pre-treatment with the UNSAP of sesame oil ameliorated the $\mathrm{CCl}_{4}$-induced liver injury, and showed a mild to pronounced degree of improvement. The liver sections of $50 \%$ of animals within this group showed a dilated congested blood vessel accompanied by an inflammatory cell infiltrate (Figure $1-\mathrm{g})$. The protective effect of UNSAP against $\mathrm{CCl}_{4^{-}}$ induced liver injury was superior compared to that of $\alpha$-tocopherol. The histopathological examination of the liver of $\mathrm{CCl}_{4}$ intoxicated rats treated with UNSAP attenuated hepatocytes degeneration and restored its normal functions. The mechanism of hepatoprotection by UNSAP is due to its antioxidant activity.

\section{CONCLUSIONS}

The investigated UNSAP were found to be effectively hepatoprotective, as evidenced by biochemical, and histopathological studies. The efficiency of those UNSAP could be due to an interaction between its components which far exceeds its antioxidant activity.

CONFLICT OF INTEREST. The authors declare no conflict of interest.

\section{REFERENCES}

AOAC 2005. Official Methods of Analysis of AOAC international, 18th ed. AOAC international, Gaithersburg, USA.

AOCS 2009. Official Methods and Recommended Practices of the American Oil Chemists' Society, AOCS Press, Champaign, Illinois, USA.

Al-Seeni MN, El Rabey HA, Zamzami MA, Alnefayee AM. 2016. The hepatoprotective activity of olive oil and Nigella sativa oil against $\mathrm{CCl}_{4}$ induced hepatotoxicity in male rats. BMC Complement. Altern. Med. 16, 438-451. https://doi. org/10.1186/s12906-016-1422-4

Bancroft JD, Steven A, Turner DR. 1996. Theory and Practice of Histological Techniques. Churchill Livingstone, New York, London, San Francisco, Tokyo.

Beji RS, Mansour RB, Rebey IB, Wannes WA, Jameleddine S, Hammami M, Megdiche W, Ksouri R. 2018. Does Curcuma longa root powder have an effect against $\mathrm{CCl}_{4^{-}}$ induced hepatotoxicity in rats: a protective and curative approach? Food Sci. Biotechnol. 27, 1-9. https://doi. org/10.1007/s10068-018-0449-3

Codex Alimentarius Commission 2015. Codex Standard for Named Standard for Edible Fats and Oils. Codex Stan 210-1999.

Echeverría F, Ortiz M, Valenzuela R, Videla LA. 2017. Hydroxytyrosol and cytoprotection: A projection for clinical interventions. Int. J. Mol. Sci. 18, 930. https://doi. org/10.3390/ijms 18050930

European Food Safety Authority. 2015. Scientific opinion on the re-evaluation of tocopherol-rich extract (E 306), $\alpha$-tocopherol (E 307), $\gamma$-tocopherol (E 308) and $\delta$-tocopherol (E 309) as food additives. E. F. S. A. 13, 4247. https://doi.org/10.2903/j.efsa.2015.4247

Farhoosh R, Tavassoli-Kafrani MH, Sharif A. 2013. Assaying antioxidant characteristics of sesame seed, rice bran, and bene hull oils and their unsaponifiable matters by using DPPH radical-scavenging model system. J. Agric. Sci. Tech. 15, 241-251.

Fontanel D. 2013. Unsaponifiable Matter in Plant Seed Oils. Springer-Verlag, Berlin Heidelberg. https://doi. org/10.1007/978-3-642-35710-7

Fukuda Y, Nagata M, Osawa T, Namiki M. 1986. Chemical aspects of the antioxidative activity of roasted sesame seed oil, and the effect of using the oil for frying. Agric. Biol. Chem. 50, 857-862. https://doi.org/10.1080/00021369.1986.10867500

Gliszczynska-Swiglo A, Sikorska E, Khmelinskii I, Sikorski M. 2007. Tocopherol content in edible plant oils. Pol. J. Food Nutr. Sci. 57, 157-161.

Ham H, Lee YY, Park JY, Lee C, Kwak J, Kim IH, Lee J. 2016. Protective mechanisms of Unsaponifiable matter from rice bran against tert-butyl hydroperoxide-induced oxidative 
damage in HepG2 cells. J. Food Biochem. 40, 526-534. https://doi.org/10.1111/jfbc.12251

Hendawi MY, Alam RT, Abdellatief SA. 2016. Ameliorative effect of flaxseed oil against thiacloprid-induced toxicity in rats: hematological, biochemical, and histopathological study. Environ. Sci. Pollut. Res. 23, 11855-11863. https:// doi.org/10.1007/s11356-016-6376-z

Illesca P, Valenzuela R, Espinosa A, Echeverría F, Soto-Alarcon S, Ortiz M, Videla LA. 2019. Hydroxytyrosol supplementation ameliorates the metabolic disturbances in white adipose tissue from mice fed a high-fat diet through recovery of transcription factors Nrf2, SREBP-1c, PPAR- $\gamma$ and NF-кB. Biomed. Pharmacother. 109, 2472-2481. https:// doi.org/10.1016/j.biopha.2018.11.120

Jain A, Soni M, Deb L, Jain A, Rout S, Gupta V, Krishna K. 2008. Antioxidant and hepatoprotective activity of ethanolic and aqueous extracts of Momordica dioica Roxb. leaves. J. Ethnopharmacol. 115, 61-66. https://doi.org/10.1016/j. jep.2007.09.009

Johnston DE, Kroening C. 1998. Mechanism of early carbon tetrachloride toxicity in cultured rat hepatocytes. Pharmacol. Toxicol. 83, 231-239. https://doi.org/10.1111/j.1600-0773.1998. tb01475.x

Krauß S, Vetter W. 2018. Phytol and phytyl fatty acid esters: occurrence, concentrations, and relevance. Eur. J. Lipid Sci. Technol.120,1-13. https://doi.org/10.1002/ejlt.201700387

Lai CY, Cheng SB, Lee TY, Liu HT, Huang SC, Huang YC. 2018. Possible synergistic effects of glutathione and C - reactive protein in the progression of liver cirrhosis. Nutrients 10, 678. https://doi.org/10.3390/nu10060678

Liu Q, Kong B, Li G, Liu N, Xia X. 2011. Hepatoprotective and antioxidant effects of porcine plasma protein hydrolysates on carbon tetrachloride-induced liver damage in rats. Food Chem. Toxicol. 49, 1316-1321. https://doi.org/10.1016/j. fct.2011.03.013

Moazzami AA, Haese SL, Kamal-Eldin A. 2007. Lignan contents in sesame seeds and products. Eur. J. Lipid Sci. Technol. 109, 1022-1027. https://doi.org/10.1002/ejlt.200700057
Narasinga Rao BS. 2001. Nonglyceride components of edible oils and fats. 2. Nutritional and health significance. Food Nutr. Bull. 22,87-93. https://doi.org/10.1177/156482650102200114

Nicco C, Batteux F. 2018. ROS Modulator molecules with therapeutic potential in cancers treatments. Molecules 23, 1-16. https://doi.org/10.3390/molecules23010084

Niranjan TG, Kumar MV, Lokesh BR, Krishnakantha TP. 1999. Influence of unsaponifiable matter from ghee on lymphocyte proliferation and erythrocyte fragility in rats. Nutr. Res. 19, 1671-1682. https://doi.org/10.1016/S0271-5317(99)00123-2

Periasamy S, Liu CT, Chien SP, Chen YC, Liu MY. 2016. Daily sesame oil supplementation mitigates ketoconazole-induced oxidative stress-mediated apoptosis and hepatic injury. J. Nutr. Biochem. 37, 67-75. https://doi.org/10.1016/j. jnutbio.2016.07.016

Ramadan MF, Showky HE, Sulieman AE. 2008. Comparison between the effect of $\gamma$-irradiation and roasting on the profile and antioxidant activity of wheat germ lipids. Grasas Aceites 59, 166-173. https://doi.org/10.3989/gya.2008.v59.i2.506

Reddy LH, Couvreur P. 2009. Squalene: A natural triterpene for use in disease management and therapy. Adv. Drug Deliv. Rev. 61, 1412-1426. https://doi.org/10.1016/j. addr.2009.09.005

Wang L, Tu Z, Wang H, Wang S, Wang X, Zhu H, Hu C, Liu Y. 2018. Flaxseed oil improves liver injury and inhibits necroptotic and inflammatory signaling pathways following lipopolysaccharide challenge in a piglet model. J. Funct. Foods. 46, 482-489. https://doi.org/10.1016/j.jff.2018.05.015

Yildiztekin F, Nadeem S, Erol E, Yildiztekin M, Tuna AL, Ozturk M. 2016. Antioxidant, anticholinesterase and tyrosinase inhibition activities, and fatty acids of Crocus mathewii - A forgotten endemic angiosperm of Turkey. Pharm. Biol. 54, 1557-1563. https://doi.org/10.3109/13880 209.2015.1107746

Zhou D, Ruan J, Cai Y, Xiong Z, Fu W, Wei A. 2010. Antioxidant and hepatoprotective activity of ethanol extract of Arachniodes exilis (Hance) Ching. J. Ethnopharmacol. 129, 232-237. https://doi.org/10.1016/j.jep.2010.03.016 